\title{
Gérard van Rijnberk (1875-1953): de eerste medisch- onderwijskundige in Nederland
}

\author{
E.J.F.M. Custers
}

\section{Samenvatting}

Gérard van Rijnberk (1875-1953), hoogleraar fysiologie in Amsterdam, schreef als beherend redacteur van het 'Nederlandsch Tijdschrift voor Geneeskunde' een groot aantal artikelen over het medisch onderwijs in Nederland in de eerste helft van de twintigste eeuw. Door zijn grote kennis en omvattende en coherente visie was hij dé autoriteit op dit gebied in die periode. In dit artikel wordt een kort overzicht gegeven van het toenmalige geneeskundecurriculum in Nederland en van Van Rijnberks opvattingen hierover en de beginselen waarop volgens hem het medisch onderwijs gebaseerd zou moeten zijn. Van Rijnberk wilde enerzijds streng vasthouden aan het oude ideaal van de breed opgeleide, academisch gevormde geneeskundige; anderzijds had hij soms verrassend moderne opvattingen over de onderwijsvormen. Zo vond hij dat geneeskundestudenten hun eigen leerproces in de hand moesten nemen en hij legde met name sterk de nadruk op zelfwerkzaamheid in laboratoria en ziekenzalen. Hoewel het geneeskundeonderwijs na 1965 een stormachtige ontwikkeling heeft doorgemaakt, kan het voor docenten en andere betrokkenen bij het hedendaagse medisch onderwijs zeker nuttig zijn kennis te nemen van dit stukje geschiedenis. (Custers EJFM. Gérard van Rijnberk (1875-1953): de eerste medisch-onderwijskundige in Nederland. Tijdschrift voor Medisch Onderwijs 2004;23(5):220-230.)

\section{Inleiding}

De datum 30 september 2003 zal voor de meeste lezers van het Tijdschrift voor Medisch Onderwijs onopgemerkt voorbijgegaan zijn. Niet helemaal terecht, want die dag was de vijftigste sterfdag van Gérard van Rijnberk, een man die met reden beschouwd kan worden als de eerste medisch-onderwijskundige in Nederland. Een goede gelegenheid om enige aandacht te besteden aan de meest spraakmakende woordvoerder van het geneeskunde-onderwijs in Nederland in de eerste helft van de twintigste eeuw. En aangezien de opvattingen van Van Rijnberk over medisch onderwijs bij uitstek representatief zijn voor de "medisch-onderwijskundige orthodoxie"1 is het belang ervan niet beperkt tot de particuliere mening van één persoon, maar weerspiegelt zijn visie in grote mate de filosofie achter het medisch onderwijs in de periode tot (globaal) het eind van de jaren zestig van de twintigste eeuw. Veel hedendaagse medisch-onderwijskundigen, opgegroeid met probleemgestuurd onderwijs, leren in kleine groepen, studentgericht leren en training van medisch-technische en communicatieve vaardigheden, zullen wel enige notie hebben van de vroegere medische opleiding (veel hoorcolleges, uitvoerige snijzaal-practica met 'kikkerproeven' en al, mondeling tentamen afleggen bij de prof), maar het zal niet altijd duidelijk zijn wat nou de achterliggende grondslag van deze inrichting van het curriculum vormde. Aan de hand van de geschriften van Van Rijnberk wil ik proberen in dit stuk deze achtergronden toe te lichten, en in te gaan op de vraag hoe deze zich ver- 
houden tot de hedendaagse inrichting van en filosofie achter het geneeskundig onderwijs.

\section{Achtergrond}

Gérard Abraham van Rijnberk werd geboren op 15 Augustus 1875 te Gouda als zoon van een Amsterdamse oogarts. Vanwege een zwakke gezondheid werd hij door zijn ouders naar Italië gestuurd, waar hij het gymnasium volgde in San Remo en van 1894 tot 1900 geneeskunde studeerde in Rome. Hoewel hij in die stad op 4 november 1900 promoveerde tot doctor in de geneeskunde, heeft hij nooit als arts gepraktiseerd. ${ }^{2} \mathrm{Na}$ enkele assistentschappen in Italië werd hij in 1909 benoemd tot hoogleraar in de fysiologie aan de Universiteit van Amsterdam. Hiermee werd hij tevens directeur van het Fysiologisch Laboratorium, destijds gevestigd aan het Waterlooplein. Van Rijnberk was mede-oprichter van het tijdschrift 'Archives Néerlandaises de Physiologie et de Phonétique expérimentale' dat verscheen tussen 1918 en 1947. ${ }^{3}$

Van Rijnberks onderwijskundige bijdragen publiceerde hij voornamelijk in zijn hoedanigheid van gérant (beherend redacteur) van het 'Nederlandsch Tijdschrift voor Geneeskunde', een functie die hij van 28 juni 1913 tot 31 december 1946 vervulde. Een medisch onderwijskundige in de hedendaagse zin van het woord was hij natuurlijk niet, maar door zijn deskundigheid en coherente en omvattende visie was hij zeker een autoriteit op het gebied van medisch onderwijs. Hij was bovendien de eerste in Nederland die zich intensief met het onderwerp bezig hield: vóór zijn tijd werd er maar spaarzaam, en dan nog voornamelijk naar aanleiding van actuele kwesties, zoals nieuwe wetgeving, over medisch onderwijs geschreven.

Van Rijnberk schreef tal van redactionele artikelen over medisch onderwijs in het 'Nederlandsch Tijdschrift voor Geneeskunde'; deze verschenen vaak in reeksen, zoals de series getiteld 'Een en ander over hooger onderwijs in de geneeskunde' (verschenen in de jaargang 1916), 'Hervorming van de opleiding van den geneesheer' (1918), 'Nieuwe banen voor de geneeskundige opleiding' (1919), 'Onderwijsvraagstukken' (1923-1924), 'De geneeskundige opleiding in Europa' (1925), opnieuw 'Onderwijsvraagstukken' (1928), en 'Enkele vragen inzake het geneeskundig onderwijs' (1942). In datzelfde jaar verscheen van zijn hand ook de brochure 'Inleiding tot de studie der geneeskunde' waarvan drie drukken verschenen, de laatste in 1946. ${ }^{*}$ Dit werkje, eigenlijk bedoeld voor aankomende studenten, laat zich lezen als een Raamplan avant la lettre: het bevat een volledige beschrijving van de toenmalige geneeskunde-opleiding, inclusief een aantal observaties met betrekking tot de achterliggende grondslagen.

\section{De Nederlandse geneeskunde- opleiding in de eerste helft van de twintigste eeuw}

Om Van Rijnberks standpunten goed te kunnen interpreteren is enige achtergrondkennis van de geneeskunde-opleiding in de eerste helft van de twintigste eeuw noodzakelijk. Het meest opvallende, vergeleken met heden ten dage, was de extreme 'compartimentalisering' van de studie: zij bestond uit vier fasen die volledig, als het ware met waterdichte schotten, van elkaar waren afgescheiden. Het eerste jaar (de propaedeuse) bracht de stu-

1* Met dank aan dr. Paul Thung, die mij attent maakte op dit werk. 
dent geneeskunde door aan de Faculteit Wis- en Natuurkunde waar hij (en een enkele zij) de natuurwetenschappelijke vooropleiding genoot, bestaande uit de vakken natuurkunde, scheikunde, botanie en zoölogie, in collegezalen waarin ook studenten scheikunde en biologie zaten. Dit was een overblijfsel uit de tijd dat deze vakken aan de middelbare scholen onvoldoende aan de orde kwamen, en de universiteiten dus de studenten nog de basiskennis moesten bijbrengen. Rond het midden van de jaren dertig bestonden er al grote bezwaren tegen deze opzet. ${ }^{4}$ Echter niet bij Van Rijnberk, die ter verdediging van de natuurwetenschappelijke propaedeuse twee argumenten aanvoert: Ten eerste, dat "de geneesheer iemand moet zijn, die althans op natuurwetenschappelijk gebied eenige algemeene cultuur moet bezitten" en ten tweede dat "niemand kan voorspellen of niet bepaalde hoofdstukken vooral der exacte natuurwetenschappen plotseling zullen blijken een breede toepassing in de geneeskunde te kunnen vinden."5

$\mathrm{Na}$ het afleggen van het propaedeutisch examen ('het propjes') begon de kandidaatsfase, die het tweede en derde studiejaar omvatte. Hierin maakte de student kennis met de geneeskundige laboratoriumvakken: anatomie, histologie, fysiologie en algemene pathologie. Dit was de meest wetenschappelijke fase van de studie; in de woorden van Arie Querido "een tweejarige studie van dode mensen en levende dieren." ${ }^{*}$ De algemene ziekteleer was het enige 'patho'-vak in die fase en vormde een soort van brug naar de studie van de zieke mens.

$\mathrm{Na}$ het kandidaatsexamen volgde de theoretisch-klinische of doctoraalfase (het vierde en het vijfde jaar). De overgang van kandidaats- naar doctoraal-student markeerde in die tijd ook de overgang van universitair onderwijs naar vakstudie. De studie werd breder, maar verloor aan diepte. Op het vak pathologische anatomie na, was er geen enkel verband met de studie van vóór het kandidaatsexamen. ${ }^{6}$ Het onderwijs in de doctoraalfase bestond vrijwel geheel uit demonstratiecolleges, en het doctoraalexamen gold als het zwaarste uit de medische studie, omdat de student op het examen alle klinische kennis paraat moest hebben. De achterliggende filosofie van deze curriculum-opzet was dat eerst een stevige kennisgrondslag van "onontbeerlijke feiten en algemeene beginselen" moest worden gelegd vóórdat de toepassing hiervan aan het ziekbed kon worden onderwezen; pas als beide voltooid waren, mocht de student zich daadwerkelijk aan het ziekbed vertonen. ${ }^{7}$ Voor de co-assistentschappen stond na het doctoraal examen nog nominaal anderhalf jaar.

De opzet van de geneeskundestudie in Nederland was hiermee gebaseerd op wat de Amerikaanse onderwijskundige Flexner het 'logische' onderwijsstelsel noemt. In dit stelsel worden eerst de beginselen en grondslagen gelegd, om daarop verder te bouwen in de praktische fase. ${ }^{3 *}$ Flexner,

2* Querido A. Doorgaand verkeer. Autobiografische fragmenten. Lochem: Uitgeversmaatschappij De Tijdstroom; 1980. p. 22. Arie Querido (1901-1983), zoon van de bekende uitgever, begon als fysioloog bij Van Rijnberk, maar stapte in 1927 over naar de sociale psychiatrie en werd na de oorlog directeur Openbare Gezondheidszorg in Amsterdam en hoogleraar sociale geneeskunde aan de GU. Tussen 1958 en 1970 zat Arie Querido voor de PvdA in de Eerste Kamer. Met moet hem niet verwarren met Andries Querido (1912-2001), de grondlegger van de Medische Faculteit Rotterdam.

3* Flexner A. Medical education. A comparative study. New York: The MacMillan Company; 1925. p.107-112. Voor de visie van Flexner op het medisch onderwijs, zie Bender W. Flexner: Een eenmansvisitatiecommissie avant la lettre. Bulletin Medisch Onderwijs 1992;11:8-13, en Bender W. Flexner over het medisch onderwijs in Europa. Bulletin Medisch Onderwijs 1992;11:52-5. 
die in 1925 een boek publiceerde waarin de geneeskunde-opleidingen in verschillende Europese landen met elkaar werden vergeleken, geeft hieraan de voorkeur boven een 'natuurlijk' stelsel, waarbij de student vanaf de eerste dag meeloopt op de ziekenzalen (het toenmalige Franse geneeskunde-onderwijs was een voorbeeld van zo'n natuurlijk stelsel). Het Nederlandse curriculum kan zelfs 'ultra-Flexneriaans' worden genoemd: waar Flexner nog duidelijk de beperkingen van het logische stelsel ziet - het is ondoenlijk een volledige studie te maken van de normale menselijke anatomie en fysiologie, alvorens zich te wijden aan de afwijkingen hiervan; het leidt gemakkelijk tot overmatige compartimentalisering; en het is lastig om de studenten gedurende langere tijd te interesseren voor de laboratoriumvakken - verdedigt Van Rijnberk het met verve. Eerst moeten de exacte en biologische natuurwetenschappen worden onderwezen, pas daarna anatomie en fysiologie, dan de klinische vakken, en pas aan het eind kunnen de studenten worden toegelaten in de klinieken. ${ }^{8}$

\section{Onderwijsvormen}

Wat betreft de vorm van het onderwijs nam het hoorcollege een prominente plaats in tot aan het doctoraal examen. Desondanks werd het zeker niet door iedereen beschouwd als de meest ideale vorm van kennisoverdracht. "Er bestaat in ons land bepaald een overdreven geloof in het nut van veel college geven," schreef Van Rijnberk al in 1916. ${ }^{9}$ Twee jaar later, stelliger: "Er wordt bij ons veel te veel college gegeven. Zonder het mondelinge les-onderwijs geheel te willen afschaffen, geloof ik toch, dat de professoren en de studenten erbij gebaat zouden zijn, als er minder colleges gegeven werden en de studenten er meer in getraind werden, zelfstandig te werken." 10 Met dit laatste bedoelde hij: zelf werken in de laboratoria en in de ziekenzalen. Want in zijn visie was er sprake van een duidelijke hiërarchie van wijzen van kennisvergaring. Onderaan staat kennis verkregen door boekenstudie, een trap hoger staat kennis verworven door omgang met andere mensen (instructie, demonstratie, en allerlei vormen van 'apprenticeship'), en bovenaan staat door de student zélf, bij voorkeur proefondervindelijk, verworven kennis. ${ }^{11}$ "Een leerboek kan zelfs beter dan een college dienen om snel wat feitenkennis op te doen, maar het eigenlijke inzicht krijgt de student alleen in het laboratorium en aan het ziekbed door zelf te zien, zelf te zoeken, zelf te doen," zo vatte hij het samen. ${ }^{12}$ Voor leerboeken gold dat ze vooral niet te beknopt mochten zijn: Van Rijnberk was een tegenstander van compendia, die alleen de belangrijke feiten bevatten, de bijkomstigheden onvermeld lieten en theoretische beschouwingen verwaarloosden. Voor colleges gold iets dergelijks: liever verdieping van enkele onderwerpen, dan een synoptisch overzicht van een vak. Colleges dienden niet om feitenkennis over te dragen, maar om studenten te leren hoe ze met de leerstof in de boeken om moesten gaan. ${ }^{13}$ Het grote voordeel van colleges boven leerboeken was dat een docent op ieder gewenst moment een excurs kon inlassen over een ander, verwant onderwerp, zodat de toehoorders goed doordrongen konden worden van het verband tussen de zaken die aan de orde werden gesteld. ${ }^{14}$

Wat betreft het demonstratie-onderwijs maakte Van Rijnberk onderscheid tussen passieve demonstraties (het tonen van voorwerpen, kristallen, gesteenten, planten, dieren, mensen of afbeeldingen, met als nieuwste snufje het afdraaien van "cinematographische films") en actieve demonstraties (proeven door de docent voor de groep studenten verricht, waarbij 
hij beschrijft en uitlegt wat hij doet). ${ }^{15}$ Hoewel demonstraties in zijn ogen een kwalitatief betere vorm van onderwijs zijn dan puur mondelinge hoorcolleges, had hij zijn bedenkingen bij het grote aantal klinische demonstratiecolleges in de doctoraalfase van de studie en gaf hij de voorkeur aan meer praktische cursussen in de kliniek. ${ }^{16}$ Met deze visie stond hij zeker niet alleen; Flexner karakteriseerde de doctoraalfase in Nederland als "two years of unrelieved demonstrative lecturing". ${ }^{17}$ Wat betreft de propaedeuse en de kandidaatsfase kon Van Rijnberk in 1942 in ieder geval verheugd constateren dat het praktisch onderwijs, dat vroeger uitsluitend beperkt bleef tot het ontleedkundig dissectiepracticum, geleidelijk was uitgebreid met onder andere het gebruik van röntgenapparatuur en met het zelf vervaardigen en bestuderen van microscopische preparaten. ${ }^{15}$

Dat de praktische cursussen het belangrijkste onderdeel van de opleiding zouden moeten zijn was een direct gevolg van de aard van de geneeskunde zoals Van Rijnberk die zag: in haar grondslag zintuiglijke waarneming, in haar uitoefening handigheid. Doel van het onderwijs was dus, naast het bijbrengen van theoretische kennis, het oefenen van de handen en de zintuigen. ${ }^{8}$ Wat betreft het anatomische (dissectie-)practicum sneed het mes aan twee kanten: enerzijds was dit een uitstekende training van de heelkundige handigheid en vaardigheid, anderzijds leerde de student zo de organisatie die de levensverrichtingen mogelijk maakt, goed kennen. ${ }^{18}$

\section{Wetenschappelijke karakter van de opleiding}

Een tweede terugkerend thema in het werk van Van Rijnberk is zijn pleidooi voor behoud en versterking van het academisch-wetenschappelijke karakter van de opleiding. Immers, het wezenlijke van het hoger onderwijs is niet het overdragen van feitenkennis, maar "het scherpen van het verstand tot begrijpen, het rijpen van de geest tot inzicht."9 De hoogleraar moet alleen díe feitenkennis aandragen, die noodzakelijk is voor studenten om vervolgens hun kennis te vermeerderen door eigen studie. In dit opzicht klinkt hij verrassend modern: "Maar men moet het vak niet willen leeren: men moet den studenten het leeren leeren. Leert men hun alleen het vak, dan kan men hun slechts een begrensd, beperkt feitenmateriaal bijbrengen, dat na één jaar verouderd is. Leert men hun zelf denken en zelf studeeren, dan geeft men hun het middel, om tot het eind van hun leven den gang der wetenschap te kunnen volgen." 9 Dit standpunt komt het duidelijkst tot uitdrukking in zijn visie op de rol van de laboratoriumvakken in de kandidaatsfase. Deze moeten vooral niet worden gegeven met het oog op hun toepassing in de kliniek, maar juist breed en wetenschappelijk. "Tal van verplichte examenvakken hebben geen enkel onmiddellijk practisch nut. Welke arts onder de velen die een draagbaar Röntgentoestel bezitten en herhaaldelijk gebruiken, past ooit de theorie der electromagnetische stralingen in het dagelijksche bedrijf toe? Welke collega onder de duizenden die de algemeene practijk uitoefenen, heeft ooit deze gedetailleerde kennis over alle banen van het ruggemerg noodig? Waartoe dienen de vlijtig geleerde namen van alle beenderen van den visschenschedel? Dat alles wordt niet onderwezen om dagelijks toegepast te worden, maar om den aanstaanden medicus een ondergrond van natuurwetenschappelijke vorming te geven." ${ }^{19}$ Elk (preklinisch) vak moet dus vanuit zichzelf gegeven worden, zonder dat rekening hoeft te worden gehouden met de behoeften van latere vakken. Dus: vóór het kandidaatsexamen géén klinische anatomie, maar 
"ontleedkunde tout court, pure, zuivere, reine ontleedkunde”. Idem voor fysiologie: "Men moet verrichtkunde onderwijzen, niet in zooverre als dat in deze of gene cliniek te pas kan komen, maar verrichtkunde, alsof alle leerlingen ijverden voor een leerstoel in de physiologie!"20 Hoewel hij onmiddellijk erkent hier wel wat te overdrijven, is de boodschap duidelijk. Het belangrijkste argument dat hij hiervoor aanvoert is dat de behoeften van de geneeskunde telkens wisselend en tijdelijk zijn. Wat vandaag een zuiver wetenschappelijk vraagstuk is, kan morgen een onmisbare klinische toepassing hebben. ${ }^{21}$ Men moet de studenten dus alles leren van het vak, dat op zichzelf belangrijk is. Slechts dan kunnen zij later de nieuwigheden volgen en zelf nieuwe wegen vinden. ${ }^{20}$

Daar komt echter nog iets bij. Naast een rol in het aanbrengen van een gedegen natuurwetenschappelijke basis, hebben allerlei op het oog 'onnutte' vakken ook een duidelijke culturele betekenis. In dit opzicht belichaamt Van Rijnberk het toenmalige academische ideaal in Nederland, dat nog sterk naar Duits voorbeeld gemodelleerd was, en waarin - naast de vakstudie - de algemeen vormende waarde sterk werd benadrukt. Hij verzet zich dan ook fel tegen het principe van de "Anglo-Americaansche efficiency”, waarbij voor elk leervak als eerste wordt gevraagd: wat is het nut ervan voor de praktijk, terwijl de algemene culturele waarde veel minder ter zake doet. ${ }^{22-23}$ Tevreden constateert hij dat dit efficiency-uitgangspunt - dat hij omschrijft als "het beschouwen van elke inspanning uitsluitend als middel tot de snelst mogelijke verwezenlijking van een doel" - op het Nederlandse hoger onderwijs nog relatief weinig grip heeft gekregen. ${ }^{19}$ Maar het baarde hem wel zorgen, en hij kwam er dan ook regelmatig op terug.
Het academische karakter van de opleiding liet daarnaast niet toe dat plaats werd ingeruimd voor wat wij nu training van attitude- of communicatievaardigheden noemen. Het kunnen omgaan met zieken, hulpbehoevenden of collega's was gedeeltelijk een kwestie van erfelijke aanleg, gedeeltelijk van oefening door ervaring, door "harde lessen in de practijk". "De Universiteit is geen vakschool en trekt zich weinig of niets van dat alles aan" hield hij de aanstaande geneeskundestudenten voor. ${ }^{24} \mathrm{Hij}$ betwijfelt zelfs of zoiets überhaupt onderwezen kan worden: "En dan, omgang met patiënten? Hoe zal men ooit algemeene regelen daarvoor kunnen onderwijzen, waar de aard der patiënten zoo sterk uiteenloopt? (-) Ik geloof, dat men niet overdrijven moet in de aan het onderwijs te stellen eischen. De finesses van het vak, wat de uitoefening als maatschappelijk beroep aangaat, moet de practijk aan den jongen arts leeren." Het universitair medisch onderwijs moet zich in zijn optiek beperken tot de technische en wetenschappelijke grondslagen van het beroep. ${ }^{25}$

\section{Van Rijnberk en het hedendaagse geneeskunde-onderwijs}

Hebben de opvattingen van Van Rijnberk nog betekenis voor het huidige geneeskunde-onderwijs, of zijn ze terecht in de vergetelheid geraakt? Terugblikkend is vooral duidelijk dat de afkeer die hij aan de dag legde voor 'efficiency' van de opleiding heden ten dage door niemand meer gedeeld wordt; integendeel, 'efficiency' is nu eerder een kenmerk van kwaliteit van de opleiding dan een 'spook'. Vanzelfsprekend valt dit in een aantal opzichten toe te juichen. De toenmalige terughoudendheid van de medische faculteiten wat betreft het onderwijzen van praktische vaardigheden heeft ertoe geleid dat artsen die afstudeerden in het 'tijdperk Van Rijn- 
berk' vaak slecht waren toegerust voor de praktijk, zowel wat betreft medisch-technische vaardigheden als in de omgang met hun patiënten. Het botweg stellen dat men nooit "algemeene regelen" voor de omgang met patiënten zal kunnen onderwijzen, heeft op zichzelf al iets onwetenschappelijks. Bovendien werd het excuus van 'academische vrijheid' - een begrip dat beschouwd kan worden als het tegenovergestelde van 'efficiency' - door studenten in het verleden vaak aangegrepen om gedurende langere tijd weinig studieactiviteiten te ontplooien, met als gevolg een uit de hand lopende studieduur en een laag rendement. In die zin kan men de "brede en diepe kennis, welke de jonge arts aan onze geneeskundige scholen opdoet" en die Van Rijnberk kenschetste als een "weldaad voor zijn leven"8 19 eerder als een ideaalbeeld beschouwen dan als iets dat daadwerkelijk in iedere student gerealiseerd werd.

Anderzijds lijkt de gedachte dat wetenschappelijke studie een vormende waarde heeft, iets dat Van Rijnberk sterk benadrukte, grotendeels uit het moderne geneeskunde-onderwijs te zijn verdwenen. Zo wordt wetenschappelijkheid gepresenteerd als een soort vaardigheid of 'competentie', en wijdt het Raamplan 2001 er welgeteld één alinea aan. ${ }^{26}$ Het begrip 'academische vorming' ontbreekt zelfs helemaal. De inhoud van het curriculum lijkt nu meer dan ooit te worden bepaald door het praktisch nut van het aangeboden onderwijs. Dit komt ongetwijfeld de professionalisering ten goede, maar het is onmiskenbaar het geval dat de hedendaagse geneeskunde-opleiding veel meer het karakter van een beroepsopleiding ('vakschool', in de termen van Van Rijnberk) heeft dan in de eerste helft van de twintigste eeuw. Alhoewel: zeer recent lijkt de academische vorming overigens weer wat meer nadruk te krijgen. ${ }^{27}$ Opvallend is dat uitgerekend in de Verenigde Staten, het land van de "Anglo-Americaansche efficiency", tegenwoordig meer aandacht lijkt te bestaan voor dit aspect van de opleiding dan in Nederland. ${ }^{28}$

Van Rijnberk moet hebben beseft dat zijn uitgesproken opvattingen over het vormende doel van het onderwijs op den duur niet houdbaar zouden zijn; aangezien hij zijn eigen standpunt in deze als "dualistisch" ${ }^{*}$ en oerconservatief" omschreef, beschouwde hij zichzelf kennelijk op dit punt toen al als iemand van de 'oude stempel'. ${ }^{23}$ Een onderwijsvernieuwer pur sang was hij dus zeker niet, maar hierbij moet er wel rekening mee worden gehouden dat de wens tot onderwijsvernieuwing in die tijd nog helemaal geen gemeengoed was. Volgens Arie Querido bijvoorbeeld kwam het in zijn tijd bij geen enkele student op, kritiek op het onderwijsprogramma te leveren. "Wij bekeken zeker in de latere jaren - de docenten zeer kritisch, nooit echter de aangeboden stof." ${ }^{*}$ En voor de docenten gold iets dergelijks. Men klaagde in de loop der jaren geregeld over groeiende studentenaantallen en krimpende middelen, maar er werd zelden of nooit gesproken over vernieuwing van het curriculum. Zo merkt Van

4* Met dualistisch bedoelt hij in dit verband dat de studie geneeskunde behoort te bestaan uit een algemeenvormende wetenschappelijke basis met pas daarna aandacht voor de praktische toepassing ervan.

5* Billroth Th. Ueber das Lehren und Lernen der medizinischen Wissenschaften and den Universitäten der Deutsche Nation, nebst allgemeinen Bemerkungen über Universitäten: eine kulturhistorische Studie. Wien: Carl Gerold's Sohn; 1876. Van Rijnberk maakt deze opmerking in zijn bespreking van het boek van J. Schwalbe, Zur Neuordnung des medizinischen Studiums. Leipzig: Verlag von Georg Thieme; 1918. p. 1. Schwalbe was in die tijd beherend redacteur van de 'Deutsche Medizinische Wochenschrift', dus eigenlijk het Duitse equivalent van Van Rijnberk. 
Rijnberk op, naar aanleiding van de stelling van de Duitse toonaangevende chirurg Theodor Billroth (1829-1894) dat elke geneeskundefaculteit minstens éénmaal elke vijf jaar haar onderwijsprogramma's zou moeten herzien, dat dit in Nederland al meer dan vijftig jaar niet meer is gebeurd. 529 Dit conservatisme van de universiteit beschouwde hij als haar kracht, maar hij was zich ook bewust van het gevaar dat erin school: als het beroep onderhevig is aan veranderende behoeften en nieuwe eisen, schiet de opleiding uiteindelijk tekort wanneer zij zich hieraan niet aanpast. ${ }^{30}$ Uit dit gezichtspunt kan worden afgeleid dat er bij Van Rijnberk eerder sprake was van vrees voor (onvermijdelijke?) verwatering van het academische gehalte van de opleiding, dan van blind conservatisme.

Opvallend is dat Van Rijnberks behoudzucht gepaard ging met zeer modern klinkende opvattingen over de opzet en vorm van het onderwijs: minder nadruk op hoorcolleges, stimuleren van zelfwerkzaamheid, en het in de hand nemen van het eigen leerproces ('leren leren'). In vroegtijdige kennismaking met de kliniek, een speerpunt van het huidige onderwijs, zag hij evenwel weinig heil: hiertoe ontbrak het de studenten aan de benodigde onderliggende basiskennis, en bovendien zou "het vertoonen van zieke menschen" weliswaar erg aantrekkelijk zijn, maar hen ook zeer afleiden van de overige studie, waardoor ze de kandidaatsvakken zouden gaan beschouwen als louter "grauwtheoretische ballast". Hierover bestond volgens hem geen verschil van mening: "Het onderwijs in de candidaatsvakken is praeclinisch en behoort dat te blijven. Student noch hoogleeraar dier vakken moeten het ziekbed naderen".31 Omdat de vakken in de kandidaatsfase enerzijds op zichzelf staan, anderzijds logisch op elkaar moeten voortbouwen, pleit hij zelfs voor meer 'des-integratie' in deze fase: de laboratoriumvakken zouden successievelijk, en niet parallel, moeten worden aangeboden: eerst de structuren, dan de functies, dus eerst de hele anatomie, dan pas de fysiologie. Om dit te bewerkstelligen had hij zelfs al eens overleg gepleegd met Bolk, collega-hoogleraar in de anatomie. Maar ja, "er is nooit iets van gekomen. In een oud organisme als de hoogeschool, enkele onderdeelen te willen gaan hervormen, is een uiterst moeilijke onderneming." 32

Omgekeerd zou in de klinische fase juist wél veel meer moeten worden gestreefd naar integratie. De strikte scheiding tussen het onderwijs in fysiologie en pathologie, interne geneeskunde en heelkunde, zag hij als een groot nadeel. "Deze scheiding heeft ook schuld eraan, dat de student zijn physiologie aan den kant doet, zodra hij zijn (candidaats)examen achter den rug heeft." 33 De oplossing zou zijn het fysiologisch instituut veel nauwer te associëren met de laboratoria voor farmacologie en pathologie, en zelfs met het ziekenhuis, niet door de zieken naar het laboratorium te brengen, maar door de fysiologie naar het ziekenhuis te brengen. Toegepaste fysiologie en klinisch onderwijs zouden in elkaar moeten grijpen. "De clinicus moet altijd physioloog zijn, de physioloog altijd een onderzoeker."33 Mogelijk was deze wens mede ingegeven door de neerbuigende houding van veel clinici toentertijd jegens de wetenschappelijke arbeid in de laboratoria: een goede arts kon in hun ogen heel goed zonder die rompslomp. ${ }^{34}$ Desondanks blijkt uit het toenmalige onderwijsprogramma dat de geneeskunde beschouwd werd als een vorm van natuurwetenschappelijke biologie, toegepast op de zieke mens. ${ }^{35}$ Dit is nog heel lang de officiële, zij het vaak onuitgesproken, opvatting in Nederland geweest: het oorspronkelijke curriculum 
van de in 1965 opgerichte Medische Faculteit Rotterdam bijvoorbeeld ademde nog heel duidelijk die geest. ${ }^{36}$ Van Rijnberk verwoordde dus de gangbare visie toen hij schreef: “(-) de geneesheer moet toch steeds in de eerste plaats natuurwetenschappelijk en vooral: exact natuurwetenschappelijk man zijn, omdat de geheele geneeskunde niet alleen berust op exact natuurwetenschappelijke kennis, maar tot in al haar onderdeelen uit de toepassing daarvan bestaat."37 Aangezien veel clinici hier kennelijk heel anders over dachten, bleef de bestaande compartimentalisering van de studie, niettegenstaande Flexner's duidelijke reserves in 1925, nog meer dan veertig jaar gehandhaafd. Pas na 1965 zou de medische studie, eerst aarzelend, maar vanaf de tweede helft van de jaren zeventig in versneld tempo, qua opzet en organisatie grondig worden aangepast.

\section{Tenslotte}

Van Rijnberk als docent is vereeuwigd door Simon Vestdijk in de Anton Wachterromans waar hij onder de naam 'Reinders' met name in het deel 'De vrije vogel en zijn kooien' (oorspronkelijke uitgave 1958) regelmatig wordt opgevoerd. Simon Vestdijk was kandidaat in de geneeskunde van september 1918 tot januari 1921 en heeft volgens tijdgenoten in zijn romans een waarheidsgetrouw beeld geschetst van zijn docenten. ${ }^{38}$ Anton Wachter zag in 'Reinders' een uitstekend docent, wiens colleges hij omschrijft als "avontuurlijke tochten, (-) niet in het menselijk lichaam zozeer als wel in de wereld der fysiologische theorieën." 39 De eerder genoemde Arie Querido, die een jaar na Vestdijk geneeskunde studeerde, geeft een overeenkomstig beeld: hij omschrijft Van Rijnberks colleges als "een intellectueel spel der onzekerheid, waarin hij de betrekkelijkheid van het experiment en van het menselijk denkvermogen liet zien."40 Maar Simon Vestdijk en Arie Querido waren geen van beide doorsnee geneeskundestudenten: beiden waren bovenmatig geïnteresseerd in de wetenschappelijke kanten van het vak, en met name in de fysiologie. Er zijn ook bronnen die melden dat Van Rijnberk saai en met tegenzin college gaf, en voornamelijk voorlas uit de door hem geschreven leerboeken (het 'Nederlandsch Leerboek der Physiologie', waarvan de eerste editie verscheen in 1937). Waarschijnlijk verloor hij stilaan zijn enthousiasme voor het geven van onderwijs, mede omdat zijn journalistieke activiteiten teveel van zijn tijd vergden. ${ }^{41}$

\section{Literatuur}

1. Brief van dr. Paul Thung aan de auteur, d.d. 30 mei 2003.

2. Rijnberk G van. Examens, diploma's en bevoegdheden. 4. De algemeene practicus. Ned Tijdschr Geneeskd 1919;63 (Tweede Helft):1861.

3. Redactie Nederlandsch Tijdschrift voor Geneeskunde. Personalia 40 jaren doctor in de geneeskunde. Ned Tijdschr Geneeskd 1940;84(IV):432930.

4. Zie bijvoorbeeld het 'Prae-advies over de opleiding van den arts', uitgebracht door de SociaalHygiënische Commissie in 1936. Ned Tijdschr Geneeskd 1937;81(IV):5019-82.

5. Rijnberk $G$ van. Inleiding tot de studie der geneeskunde. Den Haag: N.V. Servire; 1942. p. 28.

6. Querido A. Doorgaand verkeer. Autobiografische fragmenten. Lochem: Uitgeversmaatschappij De Tijdstroom; 1980. p. 29.

7. Rijnberk G van. Inleiding tot de studie der geneeskunde. Den Haag: N.V. Servire; 1942. p. 26.

8. Rijnberk $\mathrm{G}$ van. De geneeskundige opleiding in Europa, bezien door een Americaan. 9. Slotbeschouwingen. Ned Tijdschr Geneeskd 1925;69 (Tweede Helft):2068-9.

9. Rijnberk $G$ van. Een en ander over hooger onderwijs in de geneeskunde. VI. De taak van den hoog leeraar. Ned Tijdschr Geneeskd 1916;60 (Tweede Helft):1366-7.

10. Rijnberk $G$ van. Hervorming van de opleiding van den geneesheer. 3. Pearce's denkbeelden. Ned Tijdschr Geneeskd 1918;62 (Tweede Helft):1659.

11. Rijnberk $G$ van. Een en ander over hooger onderwijs in de geneeskunde. VII. De taak van den hoogleeraar. Ned Tijdschr Geneeskd 1916;60 (Tweede Helft):1454. 
12. Rijnberk $G$ van. Hervorming van de opleiding van den geneesheer. 3. Pearce's denkbeelden. Ned Tijdschr Geneeskd 1918;62 (Tweede Helft):1658.

13. Rijnberk $G$ van. Teaching of physiology and the physiological laboratory - University of Amsterdam. Methods and Problems of Medical Education 1932; Series 20:79.

14. Rijnberk G van. Enkele vragen inzake het geneeskundig onderwijs. IX. Colleges, leerboeken, klappers, repetitores (vooral vóór het candidaatsexamen). Ned Tijdschr Geneeskd 1942;86(IV):3128.

15. Rijnberk $G$ van. Inleiding tot de studie der geneeskunde. Den Haag: N.V. Servire; 1942. p. 62-3.

16. Rijnberk $G$ van. Nieuwe banen voor de geneeskundige opleiding. 4. De jongste denkbeelden in Engeland (2de vervolg). Ned Tijdschr Geneeskd 1919;63 (Eerste Helft): 824.

17. Flexner A. Medical education. A comparative study. New York: The MacMillan Company; 1925. p.261.

18. Rijnberk $G$ van. Onderwijsvraagstukken. 4. Het geneeskundig onderwijs in Engeland: De praeclinische vakken. Ned Tijdschr Geneeskd 1924;68 (Eerste Helft):206-9.

19. Rijnberk G van. Efficiency. Ned Tijdschr Geneeskd 1938;82(III):3932-3.

20. Rijnberk G van. School en leven. Ned Tijdschr Geneeskd 1921;65 (Eerste Helft):1674.

21. Rijnberk $G$ van. Onderwijsvraagstukken. 1. Anatomie en physiologie. Ned Tijdschr Geneeskd 1928;72 (Tweede Helft):6008.

22. Rijnberk G van. Onderwijsvraagstukken. X. "Efficiency", het spook der toekomst. Ned Tijdschr Geneeskd 1924;68 (Eerste Helft):1491.

23. Rijnberk G van. Onderwijsvraagstukken. 1. Doel. Ned Tijdschr Geneeskd 1923;67 (Tweede Helft): 2392.

24. Rijnberk $G$ van. Inleiding tot de studie der geneeskunde. Den Haag: N.V. Servire; 1942. p. 101.

25. Rijnberk $G$ van. Hervorming van de opleiding van den geneesheer. (Reactie op een brief van een doktersvrouw). Ned Tijdschr Geneeskd 1918;62 (Tweede Helft):1732.

26. Metz JCM, Verbeek-Weel AMM, Huisjes HJ. Raamplan 2001 Artsopleiding; bijgestelde eindtermen van de artsopleiding. Nijmegen: Mediagroep; 2001. p. 26.

27. Huisjes HJ, Denekens J. De onderwijsvisitatie geneeskunde 2003. Tijdschrift voor Medisch Onderwijs 2004;23(3):127-132. p. 129.

28. Derkse W. Vruchtbare 'nutteloosheid': het belang van algemene vorming in de context van beroepsgerichte academische opleidingen. Tijdschrift voor Medisch Onderwijs 2004;23(1):57-63.

29. Rijnberk $G$ van. Hervorming van de opleiding van den geneesheer. 1. Wat er volgens Schwalbe bij moet. Ned Tijdschr Geneeskd 1918;62 (Tweede Helft):1527-330.
30. Rijnberk $\mathrm{G}$ van. Hervorming van de opleiding van den geneesheer. 2. Wat er volgens Schwalbe af moet. Ned Tijdschr Geneeskd 1918;62 (Tweede Helft):1587-9.

31. Van Rijnberk G. Inleiding tot de studie der geneeskunde. Den Haag: N.V. Servire; 1942. p. 64.

32. Mulder J, Rijnberk G van. Onderwijsvraagstukken. 3. Vakschool of universiteit? Ned Tijdschr Geneeskd 1923;67 (Tweede Helft):2670.

33. Rijnberk $G$ van. Nieuwe banen voor de geneeskundige opleiding. 3. De jongste denkbeelden in Engeland (vervolg). Ned Tijdschr Geneeskd 1919;63 (Eerste Helft):746-9.

34. Mooij A. De polsslag van de stad. 350 Jaar academische geneeskunde in Amsterdam. Amsterdam/Antwerpen: Uitgeverij De Arbeiderspers; 1999. p. 371.

35. Rijnberk $G$ van. Inleiding tot de studie der geneeskunde. Den Haag: N.V. Servire; 1942. p. 27.

36. Binneveld JMW, Vleesenbeek HH. Medische Faculteit Rotterdam. Analyse van een experiment. Leiden: H.E. Stenfert Kroese B.V.; 1976. p. 59.

37. Rijnberk $G$ van. Inleiding tot de studie der geneeskunde. Den Haag: N.V. Servire; 1942. p. 31-2.

38. Visser H. Simon Vestdijk. Een schrijversleven. Utrecht: Uitgeverij Kwadraat; 1987. p. 92.

39. Vestdijk S. Anton Wachter - Amsterdam. De vrije vogel en zijn kooien [oorspronkelijke uitgave 1958]. Amsterdam: Nijgh \& Van Ditmar; 1999. p. 297.

40. Querido A. Doorgaand verkeer. Autobiografische fragmenten. Lochem: Uitgeversmaatschappij De Tijdstroom; 1980. p. 25.

41. Mooij A. De polsslag van de stad. 350 Jaar academische geneeskunde in Amsterdam. Amsterdam/ Antwerpen: Uitgeverij De Arbeiderspers; 1999. p. 355-6.

\section{De auteur:}

Dr. Eugène J. F. M. Custers is als onderzoeker Medisch Onderwijs verbonden aan het Onderwijsinstituut van het UMC Utrecht.

\section{Correspondentieadres:}

Dr. Eugène J. F. M. Custers, UMC Utrecht, Onderwijsinstituut (Bestuursgebouw), Postbus 85060, 3508 AB Utrecht, tel: 030-2532996, fax: 030-2538200, e.j.f.m.custers@med.uu.nl. 


\section{Summary}

Gérard Van Rijnberk (1878-1953) was professor of physiology in Amsterdam. As Editor-in-Chief of the Dutch Journal of Medicine he published numerous papers on medical education in the Netherlands in the first half of the twentieth century. His thorough knowledge and coherent and comprehensive insights on the subject made him the leading Dutch authority on medical education of the time. This paper presents a concise description of the medical curriculum in those days and Van Rijnberk's beliefs in respect of the principles of good medical education. Van Rijnberk was a fervent believer in the old ideal of a broad academic education for physicians (as opposed to vocational professional training). However, he also advocated the use of educational methods which definitely hint at modern approaches. For example, he emphasized that students should be taught to take control of their own learning process (learning to learn') and be offered extensive hands-on experience in scientific laboratories and in the wards. It is argued that Van Rijnberk's views may reflect a part of the history of medical education in the Netherlands that continues to be of interest to today's medical educators and medical teachers. (Custers EJFM. Gérard van Rijnberk (1875-1953): the first medical educator in the Netherlands. Dutch Journal of Medical Education 2004;23(5):220-230.) 